operative framing of projects and problems, and in experimenting. I surmise that many of our friends if they investigated the subject, would find they had been using study supervision, tho not distinguished by that name. I submit the data which are obvious.

E. Do You USE SUPERVISED STUDY. TES-38. No-38.

General Plan of Study Supervision.

Divided Period-24, Conferences-10, Alternate Period-2.

In closing let me acknowledge my indeltedness, for inspiration, support, or aid, to Dr. A. H. Hall-Quest of University of Cincinnati, Dr. L. V. Roos of University of Washington, to the commercial department of Hughes High school, and to the editor of General Science Quarterly, but most of all to the eighty coworkers who answered a rather lengthy questionnaire.

\title{
A Remedy for the Congeśtion of Subject Matter in General Science.
}

\section{Louise Nichols, Head of Dept. of Science, South Philadelimia Higir Scilool yon Gimls.}

Listening not-long ago to a debate carried on by teachers of English in high schools and colleges, $I$.was struck by a similarity in the nature of the controversies which rent them and those disturbing the peace of laboratories of science. The fiercest battle raged about the question of the practical versus the ideal as legitimate aims in teaching. There were those among the disputants who apparently believed that no sordid details of material benefits to be derived should come between the mind of the student and the contemplation of "the best thiat has been thought and said" in the world's history. They referred to "business English". with the same ajr of disdain that the corresponding type of science teacher uses in speaking of "grease spot chemistry".

It is perhaps not difficult to comprehend this state of mind and to allow for it. The devotee of perfection of style has spent hours in the study of masterpieces of English and in the effort to approximate his own writing to their lofty standards, while the earnest seeker for scientific truth has schooled his mind to minute observation, precise measurement and strict application of logical process- 
es. Holding these high ideals constantly in view in their own work and realizing so keenly the time and patience reguired to attain them, attempts to divert their energies into what seem to them meandering byways are naturally resented. Back of their reluctance too, and less often coming to the light in public discussions, I can not help suspecting personal preference. Confronted with the task of instructing some dozens or hundreds of immature minds the extreme classicist, be he an instructor of English or science, feels that to be successful he must teach whole heartedly and with enthusiasm. Practical applications he loathes and therefore follows the path of least resistance and continues to direct the attention of his pupils to the "best that has been thought and said ir literature and science. The more utilitarian minded realist may yield to the same temptation of following personal inclination ard neglect entirely the bronder or more alsstract aspects of the subject he teaches. "Essay English" or "formula chiemistry" fill him with impatience, therefore he avoids them.

Lifted beyond the region of personal inclination and recrimination, the question becomes, however, real and important to the present and future lives of school boys and girls. Is the unorement now permeating all branches of education permanent? this movement towards a more constant, direct and intimate contract between-I was going to say renl life and school life-but is seems alssurd that school life should not be real and the question in the asking answers itself. Surely it is a morement that has come to stay and is bound to progress, not, as extremists would have us believe, one of the many fads and eccentricities which hamper human endeavor.

If, then, as we are told on all sides, the present duty of school masters and mistresses is more than erer to train boys and girls for a speedier efficiency and a more complete harmony with the keynote of modern progress, social service, it behooves us to sternly suppress private preferences and to survey the field with all the impartiality we can muster. As teachers of science we should ask ourselves,-What kind of scicnce is at present taught? Is it fulfilling expectntions? Are any modifications needed to make it more eftective in the future? If so, in what direction should improvement be made? Do we need more emphasis on things practical or on mental discipline and abstraction? Is it possible profitably to combine the two? I have tried for my orrn purposes to find answers 
to these questions and welcome the opportunity to lay the results of $m y$ inquiry before the readers of the General Science QUARTERLY hoping that some of them, from their experience, may be able either to reinforce or to correct my conclusions.

The science prevailingly taught is, as we all know, generally. divided into such special subjects as physics, chemistry, biology (often subdivided into botany, zoology and physiology) and geography. In high schools, public and private, and in the colleges, laboratory work is the rule, often carried out by the students from printed directions and illustrative of certain scientific principles considered desirable for them to know. Many of the text books used open with a chapter in which fundamental conceptions are defined (matter, density, weight, elements, compounds, etc.), proceed in the following chapters to the explanation of certain laws involving these conceptions and give, either incidentally or at the end of each chapter, illustrations of the applications of these laws,

Within the last few years, in response to the growing demand especially in manual training; trade and vocational schools, for a closer relation to actual life, text books and laboratory manuals have been appearing which subordinate principles and definitions and deal more directly with daily experience, but for general high school courses a modification of the method pursued in colleges is still the rule.

An attempt to answer the question as to whether this way of presenting the subject to high school students has met with success has been made by Elliot $R$. Downing in articles published in the General Science Quarterly for November, 1917, and in . Science for October 12th, 1917. By means of figures taken from the Report of The United States Commissioner of Education, he shows that there has been a decrease, during the period 1910-1915, in the percentage of students taking the "old line subjects" in science which is not compensated for by the percentage taking more recently introduced subjects such go agriculture and domestic science and draws therefrom the conclusion that "it is fairly evident that the high school science course is in some way out of joint with the times." While this may in truth be the case, it does not necessarily follow from the figures of the United States Commissioner. In the year 1909-1910 the percentage of high school students enrolled in science was 91.99 , in 1914-1915 is was 81.16. This does not of 
course mean that fewer students were taking science in the latter year. On the contrary it means that more were, for during the period 1909-1914 the total high school enrollment increased $45.1 \%$. For every 1000 students in high school during 1909-1910 there would be in 1914,1451 , therefore for every 920 pupils studying science in the former year there would be, in the latter ycar, approximately 11\%. It does nevertheless mean that for npprosimately 276 out of every 1000 science is considered to be of little if any value. A possible explauntion for this may lie in the fact that an increasing number of students are entering commercial courses and the time required for subjects more directly related to office practice and the making of a living by clerical work crowd out from the curriculum scientific subjects along with the classic lnnguages and masterpieces of English literature.

Concerning the interest of the pupils themselves it is hardly fair to use these statistics as a test, since the opportunities for election of subjects in high school are extremely limited and often more apparent than real. The figures are more indicative of how far the makers of curricula consider science importanit. Perhaps more light may be thrown on the question of student interest if the proportion of students electing science in non-technical colleges is compared with the proportion election other subjects. If science courses in high school have made the subjects vital and have aroused the desire to know'more about it the proportion continuing its study in college should be relatively high.

The necessary infotmation is furnished by the investigations of Dr. Frederick C. Ferry of Williams College supplemented by those of W. LeConte Stevens of Washington and Lee University. (Science Oct. 24th, 1913 and Jan. 1st, 1914). Dr Ferry tabulated the registration of academic students taking various subjects in eighteen representative colleges and universities, coclucational as well as those exclusively for men or women. The subjects fell into three groups: I. Languages (classic and modern). II. Humanities (including English). III. Sciences- (including mathematics). Reduced to "student hours of instruction" and calculated in percentages, Dr. Ferry's results were for the I. and III. groups respectively 24.50 and $28.72 \%$, for Group II. $46.78 \%$. Prof. Stevens, from these results, derived a value $P$ expressing numerical$1 y$ the average demand for any given subject in the eighteen institutions. The average value of the sixteen subjects. represented in 
the table was a little over 6 which was therefore taken as a "rough standard for comparing the student demand for different subjects". This average was not reached by astronomy, Greek, geology, physies, Bible study, Latin, Political science or biology. It was reached by philosophy and chemistry and exceeded by economics, modern languages, mathematics, history and English. Plainly science in the colleges is not highly popular. It is interesting to note that chemistry, which appears as the most popular or the least unpopular of the sciences in college is also the only science which in the Commissioner's Report shows a slight gain in the high schools in the period 1910-1015, namely from $7.13 \%$ to $7.63 \%$ : Chemistry is likewise the sulject which carliest responded to the demand for closer approximation to practical living.

Evidently science in the high schools has not been an unqualified success, if the interest shown by the students be a test. Close on the heels of this demonstrated fact comes the query,-What is the trouble? In a scientific age can not, must not the subject be made of vitnl interest and importance to the rising generation? How can it be done? This is the problem which the editor of the Gexrenar. ScIENCe QUaRTERLY and his collaborators have clearly seen and are striving to solve. General Science, being a new departure and therefore comparatively unimpeded by tradition, offers an opportunity for the experimental solution of the question and experiments are being tried wherever it has been possible to introluce general science into the curriculum. This is perhaps an explanation and a compensation for the chaotic condlition of expert opinion on the sulject. I gather from $m y$ rdading of articles that have appeared in this journal that whenever the experiment has been tried of presenting to the children problems such as arise in the course of their daily experienee and of showing them how these problems may be solved by the aṕplication of "organized common. sense" not necessarily subdivided into chemistry, physics or bi: elogy, that interest has been shown and curiosity aroused. Thatever criticisms have been leveled at this method have not been on the score of lack of an appeal to the real needs of the children. They have rather been that general science tends to be orercrowded and the material arranged without sufficient cohcrence. That the children's attention is held and their efforts stimulated is something very valunble gnined. Coordination and rearrangement may be expected to follow with increasing experience and repeated cxperiments. 
Heretofore this method of applying observation, experiment and reasoning to the affairs of everyday life has not extended beyond the 9 th Grade. If, however, it has proved itself of value thus far and teachers are struggling with the overabundance of material thus secured, why not extend the same method to the remaining years of high school, why not continue to deal with daily experience as it is presented and not artificially confined within the boupdarics of the special sciences? Are there essential advantages to be derived from studing chemistry as chenistry, biology as biology, etc. that would be foregone by such an extention and which would not be compensated for by the increased interest which the' specialized sciences have not shown themselves able to maintain? The answer to this depends largely upon what it is believed desirable that high school boys and girls should get from their science study. The method of presenting the sulject whicli has been in general use for the last twenty-five years has come down to the high school from the college and the college entrance examinations accurately guage what it is that the colleges require from the instruction of the high school. The following are questions taken from the groups of five, all of which must be answered and which are supposedly considered essential in the entrance examinations of 1916 in chemistry;-Define the terms "molecule", "atom", and "ion". State Avogadro's hypothesis, and show how it guides the chemist in determining molecular weights. Calculate the percentage of oxygen in crystallized copper nitrate.

College professors of science might be disposed to doubt whether the proposed method would give students sufficient familiarity with laws, definitions and calculations. On the other hand those directly engaged in teaching high school science and striving to fit the chilidren for the responsibilities of actual life, which are likely to be unusually heavy in this century, will be inclined to inquire whether such faniliarity can not profitably be postponed until college years while the high school devotes its energies to familiarizing the children with the real mature of life's daily experiences and the kind of observation and thinking which will enable them to understand and adapt themselves intelligently to its concrete situations.

Those who have taught students of high school age can not fail to have noticed that the minds of the majority are essentially 
concrete. The often heard complaint "It was like pulling teeth to get that from the class" usually comes ofter a struggle for a definition of some abstract idea or proposition. The Greeks among high school students are few. They are chiefly Romans and Phoenicians and assimilate only the tangible and the useful. It may be said however, that chemistry as chemistry or physics as physics may be made tangible and useful and that there is no necessity for disturbing the traditional boundaries between the sciences. That special sciences can be so presented is without doubt true. Very excellent text books have appeared which demonistrate it. Nevertheless if we wish to bring home to the extremely concrete minded average high school student with the greatest possible emphasis the application of scientific principles to daily life, we must reproduce as nearly as practicable in school the actual conditions of real life where phenomena are rarely purely physical, chemical, etc. Every alsstraction from the real lessons by so much the appeal and the vividness of the instruction.

If we cast aside then our inherited attitude towards the teaching of science and attempt without bias to discover the concrete experiences which.are hestadapted to give young people the sort of knowlelge and training...rhieh will best fit them to appreciate the part that science plays in modern life, we shall be less likely to include in our courses information little used and therefore soon forgotten after graduation.

Two years ago I undertook, as head of the department of science in the South Philadelphia High School for Girls, to plan courses in science which would, as far as possible, meet the needs and interests of young girls. I gratefully acknowledge that the undertaking was begun under unusually favorable circumstances. The. school was new and headed by an exceptionally liberal minded principal. The curriculum of the high schools in Philadelphia had not become rigidly standardized and, last but not least, I had the corlial cooperation of the other teachers in the department.

The first year of science is required of all classes and consequently must be adapted to a variety of pupils, i. e., those leaving school at the end of the first year as well as those taking commercial, home economics, academic and college preparatory courses. It secmed advisable, therefore, to give in the first year an introductory course which would furnish those who take no more science with some idea of the method and the fundamental inter-relations and applications of the sciences, while at the same time laying a foundation for more 
advanced courses. It is pursued for five school periods a week and aims to give the children in the simplest possible way an insight into the real nature of such universal features of the environment as water, air, metals and mineral salts, how their properties make then of use to us in daily life, how living things in the form of green plants utilize them to make organic substances also useful to us, how other living things (fungi) break up organic material into simple substances again and cause decay, how animals depend on sulsstances elaborated from the environment by plants for their existence and finally how certain forces as distinct from the material of the environment aid living things, man as well as animals and plants, in making use of the materials of the environment and in aciapting themselves to it. I have found that this results in giving the children a familiarity with the commonest of the elements (carbon, oxygen, nitrogen, sulphur, phosphorus, etc.), the simplest of their compounds (carbon dioxide, oxide of iron, water, quick lime, etc.) and of the part they play if every day life (burning, breathing, boiling a kettle, rusting of 'iron, -ete.)- (They appreciate also the part that plants play in making food for us and gain an elemejtary knowledge about their manner of life which can be practically spplied in home and school gardening. The study of animals gives them a first hand acquaintance with the fundamentals of structure, physiology and reproduction which serves as a lackground for human hygiene. They also obtain an idea of what is meant by heat, light, electricity and sound and of the way these forces operate in such common occurrences as the ringing of a door bell, the boiling of water, the heating and lighting of a house.

The second year course I have called Howsehold Science and have divided it into four main topics, j. e., Fuel, Building Materials, Foocl, and Clothing. To the developmenteof these topics all of the sciences contriluute. For example, biology aids in the understanding of the origin of peat and coal, of the properties and preparation of lumber, of the production and preservation of food and of the source and character of textile fibers, physics throws light on the proper management of a fire, the production of gas, the utilization of matcrials for the construction of buildings, tools and cooking utensils, while chemistry explains many of the processes used in the preparntion and cooking of food and the manufacture of building materials and clothing. Necessarily there is constant reference to the information gained during the first year, not only a review of 
the facts, but further applications of them and the addition of new but related knowledge. By the end of the second year, the formerly strange hydroxides, acids and salts with names and formulae difficult to remember have become more or less familiar acquaintances, bacteria and insects are seen more clearly to be both friend and foes and the practical value of heat and electricity are realized more completely.

Since the school is but two years old, the third year course has not yet been given. . It is proposed that it should deal with the relations of science to undertakings which serve the needs of the community and may appropriately be called Civic Science. Such subjects as water supply and sewage disposal, sanitation, weather prediction, telephone and telegraph service, transportation, sources of power, printing, public recreation would come under this head. Agoin all of the sciences would be drawn upon in developing the topics and frequent incorporation of the work of previous years would be inrolved.

A discussion of the pollution of the water supply and its purification will necessitate a review of the previous work on the properties of soils, filtration, solution, lrard and soft water, and the action of bacteria in decomposing organic matter and forming nitrates, while introducing as new material the simpler chomical tests for impurities and the geological formation of the Schuylkill and Delaware River water sheds. Closely connected with the subject of water supply will be the study of waste disposal and the ralue of sanitary plumbing. To understand this and the mechanics of the water supply, the students will need to become familiar with laws of physics pertaining to water and air.

In taking up the precautions practised by city authorities to prevent the spread of desease and to preserve human life, what knowledge of bacteria the students have already. acquired will be further extended and correlated with the chemical nature and the action of disinfectants and antiseptics. Cultures of bacteria from various localities will serve to illustrate the danger of infection and the methods used to isolate different strains of bacteria. If time permits some of the more inportant devices used for diagnoses and disease prevention, such as $x$-rays, vaccination and serum injection will be included.

A review of evaporntion, condensation, convection, etc., will make plain the use of reather instruments and the significance of weather 
charts, while conditions favorable or unfavorable to plant life must be recalled in discussing the importance of weather prediction.

The subjects of transportation and sources of power, since. they are in practice so inseparable, must be considered more or less closely in relation to each other. These as well as the study of the means of communication, ought considerably to enlarge the student's knowledge of physics and its most recent applications.

The same end would be served by a study of the acoustics and lighting of places of public amusement, of stereopticon, moving pictures machines, instruments of the orchestra and phonographs.

Not yet having given the third year course I am unable to say how much of this sort of ground can be covered, but, judging from the experience of the first two years, possibilities for subject development will be elastic and time limit rigid.

Altho the approach to the subject in the first three years is invariably through practical necds and interests, the theoretical side is not entirely neglected. M[olecular and atomic theories, catalysis, hydrolysis, allotropy, the writing of formulac and equations, the distinction between force and work, the laws of work, the laws of conservation, of pressure in liquids and gases, the laws of reflection and refraction, the wave theory, the nature of noise and musical tone, and other more or less theoretical matters are touched upon in explaining phenomena. It is intended, however, in the fourth year to go more thoroughly into the nature of scientific theories and hypotheses, the intellectual necessities that gave rise to them and the effect they have had on the world's progress. Within the five periods a week allowed the ground covered would necessarily be limited, but it is hoped that it will be possible to give the class some idea of present theories concerning the constitution of the earth and its position in the solar system, of the gradual development of the conceptions which underlie these theories, of the men who devoted their lives to giving these conceptions a firm foundation and of the difficulties they met and overcame. This may be followed by an account of how we have arrived at an idea of the age of the earth and of the forces which have shaped it.and of our gradual appreciation of the real nature of earth, air, water and fire. It is intended also to show how theories concerning living things have been cleveloped and of the immense influence they have had on modern thought and action as well as to outline the theoretical basis of some of the most important inventions. 
I have been moved to plan such a course as a climax to the high school science studies, not only because it will afford numerous opportunities to review and to bring into broader relations concrete facts and simple generalizations already assimilated, but also because of the need so often felt by workers in theoretical science of a wider knowledge by the public of the value of their labors, of their difficulty and of the time they consume. To prevent the course from becoming bookish and remote exercises will be required of the students, such as observations of the heavenly bodies, of the effects of wind, waves and weather, examinations of fossils and different kinds of rocks and as far as may be practicable experiments illustrating the more important laws or hypotheses.

The four years course which I have described is taken by academic students, except college preparatory students. Commercial students are required to take the first year of science and, in the fourth year, one half year of commercial geography. They may also elect the second year of science if they so desire. Inasmuch as the subject of commercial geography is treated under the topics Fuel, Building Materials, Food and Clothing with regard to the factors which influence the areas of their production, distribution and sale, it is a distinct advantage to the commerdial students to have had the foundation which the second year of science affords. For the hygiene required of all students in the last year, the work $-:$ : the preceding years gives also a background, as by that time such subject as the nature of oxygen, carbon dioxide, osmosis, acids, bases, salts, carlohydrates, fats and protein, solution, emulsion, outlines of anatomy, physiology and reproduction, qualities of text!le fibers, chemistry of cooking, ctc. are familiar.

Altho the course is now only in the second year of its trial, I have as yet seen no reason to think that we have chosen the wrong path. I feel sure that the general science idea has virtues which are worthy of application beyond the ninth grade and that such an extension of its scope will go far to relieve the congestion and incoherence universally complained of at present. With more time in which to cover the field, the various topies will fall more easily iato their natural relations. On the other hand, the greater precision of method and abstraction of ideas required by the specialized sciences as now taught and which have but little appeal to the arerage high school student will find their proper place in the college curriculum. 